\title{
繰返し荷重を受ける短繊維の 引抜き抵抗性の評価
}

\author{
中家 康宏 1 ・國枝 稔 2 \\ 1 学生会員 岐阜大学大学院 工学研究科社会基盤工学専攻（干501-1193 岐阜県岐阜市柳戸 1-1） \\ E-mail:v3121024@edu.gifu-u.ac.jp \\ 2 正会員 岐阜大学教授 工学部社会基盤工学科（干501-1193 岐阜県岐阜市柳戸 1-1） \\ E-mail:kunieda@gifu-u.ac.jp
}

\begin{abstract}
繰返し荷重下における繊維の引抜き抵抗挙動の評価を目的として, ポリプロピレン（PP）繊維と鋼繊維 を対象とした試験を行った．PP 䋊維は繰返し荷重を受けることで䋊維表面が損傷し破断するものや，マ トリクスに割裂ひび割れが生じ，引抜き抵抗力が低下寸るものが確認された．鋼瀻維では繰返し載荷にお ける除荷過程と再載荷過程において, 引張方向及び圧縮方向の双方向において摩擦付着力による抵抗挙動 が確認され, 繰返し回数の増加に伴う付着力の低下は僅かであった.
\end{abstract}

Key Words : PP fiber, steel fiber, pull-out resistance, cyclic loading

\section{1. はじめに}

繊維補強コンクリート（以下，FRC）の力学挙動を解 析的に推定するためには，短繊維-マトリクス間の付着 メカニズムを明らかにし，数值解析の構成則として適切 にモデル化する必要がある。 これまでに，短繊維をマト リクスに埋め込んだ供試体を用いた引抜き試験が行われ， そのメカニズムの解明が進められきた.

Naamman ${ }^{144)}$ は，短繊維の付着特性と複合材料の材料設 計の関係について体系的に示し，特に繊維形状の改良に よる付着特性の改善と, 複合材料の性能改善について実 験的に検証している。. また， $\mathrm{Li}^{\mathrm{j}} \mathrm{5}$ 一短繊維の付着特性を 直接的に材料設計に反映させ，特にひずみ硬化挙動を得 るための条件を導き出している.

$\mathrm{Li} \zeta^{8)}$ 队 Kanda and $\mathrm{Li} \mathrm{i}^{9}$ は, 埋込久角度を持つ短瀻維の 引抜き試験を行い，埋込み角度が大きいほど引抜き抵抗 力が大きくなるスナビング効果，ならびに埋込久角度が 大きいほどみかけの繊維強度が低下寸る効果を実験的に 明らかにしている。

引抜き試験結果を数值解析の構成則として直接用いた 研究に関しては, Bolander and Saito ${ }^{10}$ ほ，離散化した短繊 維をはり要素を用いて再現し，マトリクスとの付着をリ ンク要素を用いて破壊解析を行っている。また, Bolander ${ }^{11)}$ や Kunieda ら ${ }^{12}$ は，短緎維とマトリクスの相互 作用を，サイズゼロのリンク要素を用いて再現し，自由
度を増やすことなく解析する手法を開発している．また， 小倉ら ${ }^{13)}$ は，鉄筋補強された FRC の引張破壊に対して メゾスケール解析を行い，精度よくその挙動を再現して いる.

以上のように，短繊維の引抜き試験による付着特性の 評価ならびにそれに基づいた材料設計や数值解析手法も 提案されている，一方で，FRC の優位性を発揮させる 構造利用として, 而震補強など, 繰返しの荷重を受ける 部材がある ${ }^{14,15.1}$ 。しかし，短繊維とマトリクスの付着に 関しては，繰返し荷重下での知見は少ないのが現状であ る.

本研究では, 繰返し荷重下での短繊維の引抜き抵抗性 を実験的に検討し，そのメカニズムについて考察するこ とを目的とした.

\section{2. 実験的評価}

\section{(1) 実験概要}

これまでの引抜き試験は，大別すると 2 種類の方法に よって行われてきた. 1 つ目は短䋊維の一端のみをマト リクスに埋込み，短繊維の片側を掴んで引き抜く方法で ある ${ }^{2}$. この方法は引抜かれる短䋊維の長さが決定して いるため短繊維-マトリクス間の付着特性の同定に適し ている. $2 つ$ 目は短䋊維の両端がマトリクスに埋め込ま 
表-1＼cjkstart短䋊維の各パラメータ

\begin{tabular}{|c|c|c|c|c|}
\hline 短䋊維 & $\begin{array}{c}\text { 繊維径 } \\
(\mathrm{mm})\end{array}$ & $\begin{array}{c}\text { 繊維長 } \\
(\mathrm{mm})\end{array}$ & $\begin{array}{c}\text { 弾性 } \\
\text { 係数 } \\
(\mathrm{GPa})\end{array}$ & $\begin{array}{c}\text { 破断 } \\
\text { 強度 } \\
(\mathrm{MPa})\end{array}$ \\
\hline \hline $\mathrm{PP}$ 繊維 & $0.5 \times 0.9$ & 48 & 10 & 530 \\
\hline 鋼䋊維 & 0.62 & 30 & 210 & 1270 \\
\hline
\end{tabular}

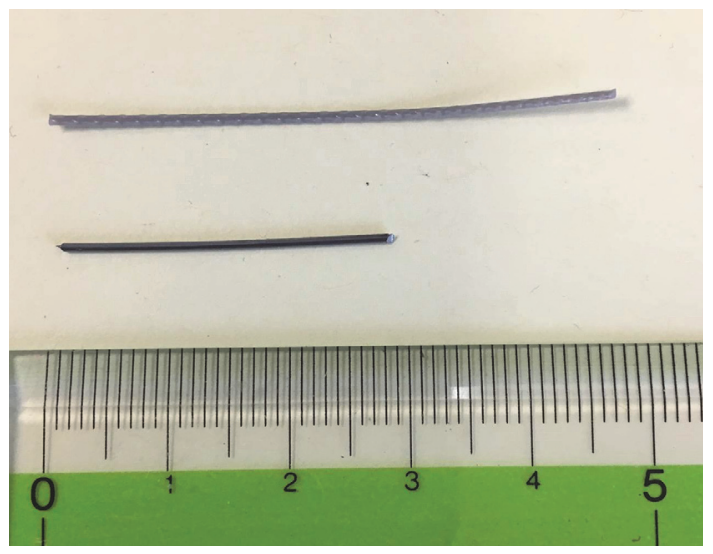

$\mathrm{PP}$ 䋊維と鋼䋊維の概形（上：PP 繊維, 下 : 鋼䋊維)
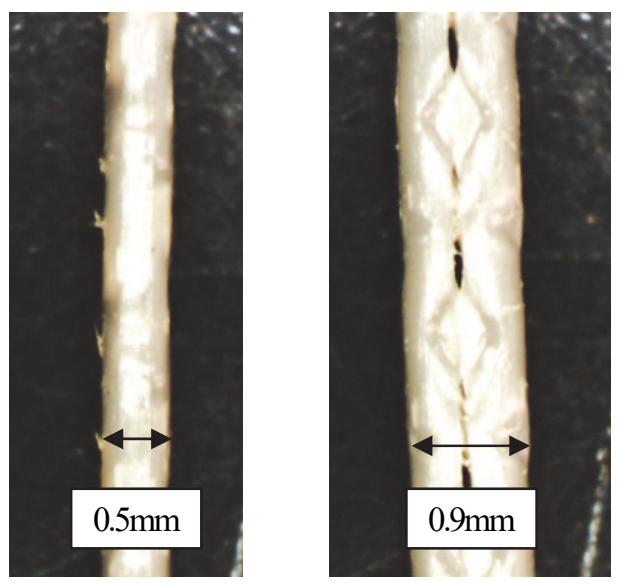

PP 繊維の拡大写真 (左 : 側面幅 $0.5 \mathrm{~mm}$, 右 : 正面幅 $0.9 \mathrm{~mm}$ )

図-1＼cjkstart使用した繊維

れた状態で，片方のマトリクスを掴んで引抜く方法 3)で ある.この方法は，短繊維の両端がマトリクスから引き 抜かれるため，引き抜かれた長さを決定するのは比較的 困難ではあるが，実際の FRC ではひび割れ面に対して 短繊維の両端がマトリクスに埋め込まれているため実現 象に近い挙動を知ることが可能である.

本研究では短繊維に対して，引抜き力に加えて，押込 み力を与えるため, 2 つ目の方法を参考に試験を実施し た．既往の方法ではあらかじめ短繊維が差し込まれた薄 い板を配置し打設することで模擬ひび割れを形成するが, 板の厚さだけ打設されていない領域が形成されること， ひび割れ発生とともに生じる付着剥離が再現されないこ とから，実現象により近い挙動を再現するために，短緎 維が配置されたマトリクスに切欠きを入れ，引張力を与
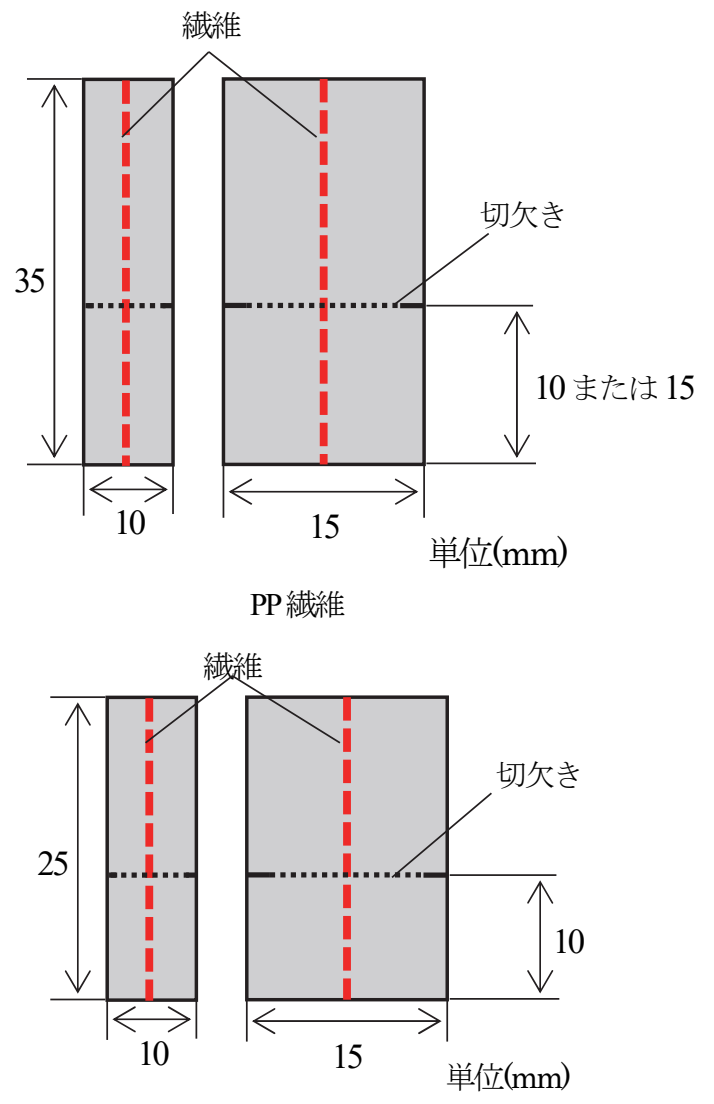

鋼繊維

図-2 供試体概要

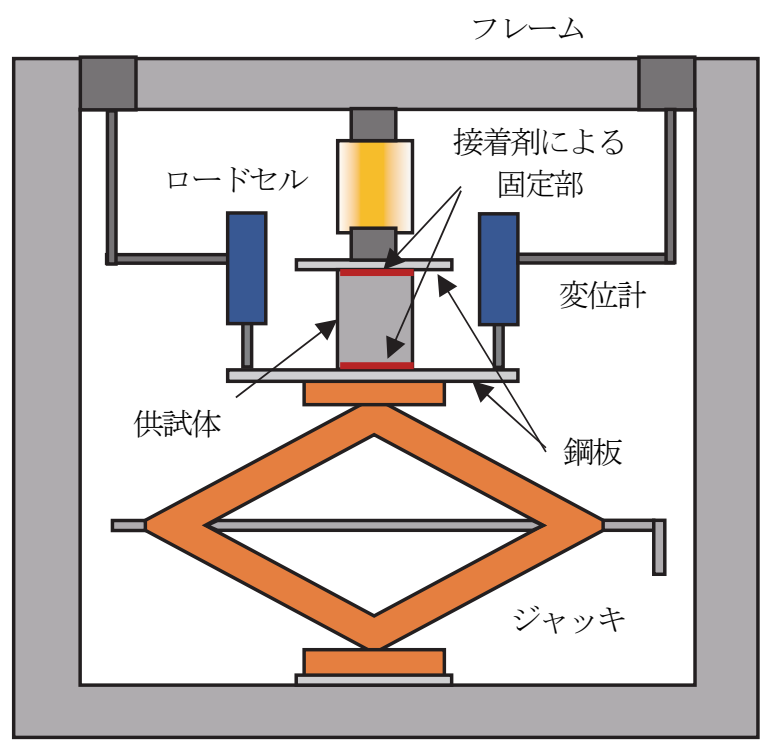

図-3 試験装置概要図

えてひび割れを発生させる方法を適用した，この際，切 久きの位置を変えることで短繊維の埋込み長を調整した 実験には表-1 ならびに図-1 に示すインデント付き PP 繊 維（以下，PP 繊維）とストレート鋼綫維（以下，鋼繊 維）を用いた。通常用いられる鋼繊維は両端がフック状 のものも多いが，その引抜き挙動におけるメカニズムは 複雑であると推察されることから，供試体の作製段階で 
フックを切り落とし，まずはストレート形状のものを対 象とした実験を行った. ストレート形の挙動が把握でき れば, 将来的にフック付き繊維の結果と比較検討し，フ ックの影響を定量的に取り出すことができ，さらに引抜 き抵抗性の高い形状寸法の提案も可能となる.

\section{（2）供試体作製}

供試体の作製手順は，まず型枠に短繊維を配置し，水 セメント比 50\%のセメントペーストを流し込むことで平 板供試体を作製した，その後，マイクロカッターを用い て所定の大きさの供試体を切り出した. 切り出した後の 供試体端部には繊維の断面が観察されたが, 䋊維の断面 はスムーズであり,引抜き挙動に影響しないと推察した。 作製した供試体の概要を図-2 に示寸，短繊維の埋込み 長は, 切欠き位置を変えることで調整した. 切欠きの深 さは，PP 繊維ではひび割れが生じる断面積（リガメン 卜の面積）がおよそ $100 \mathrm{~mm}^{2}$, 鋼繊維の場合は $25 \mathrm{~mm}^{2}$ と なるように側面の4面に加えた.

\section{(3) 試験方法}

短繊維が埋め込まれた供試体に単調引抜き荷重および 繰返し荷重を与えるために，図-3に示寸試験機を用い た。供試体と試験機は接着剤を用いて接着し，ジャッキ により引張力または圧縮力を与えた．単調引抜き荷重は, $1 \mathrm{~mm} / \mathrm{min}$.を目安に作用させた. 繰返し荷重は, 引張方向

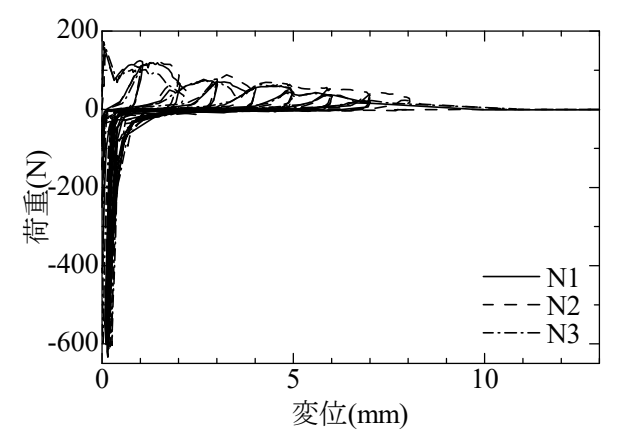

全体

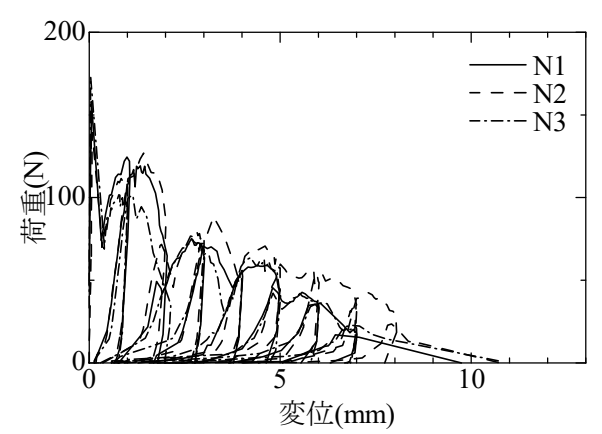

$0 \mathrm{~N}$ 以上のみ拡大（作用させる圧縮力 $600 \mathrm{~N}$ )
表-2 検討パラメータ

\begin{tabular}{|c|c|c|c|c|}
\hline 種類 & $\begin{array}{l}\text { 埋込み } \\
\text { 長 }(\mathrm{mm})\end{array}$ & 載荷方法 & $\begin{array}{c}\text { 作用 } \\
\text { 圧縮力(N) }\end{array}$ & $\begin{array}{l}\text { 本数 } \\
\text { (本) }\end{array}$ \\
\hline \multirow{6}{*}{$\begin{array}{c}\mathrm{PP} \\
\text { 繊維 }\end{array}$} & \multirow{3}{*}{10} & 単調 & - & \multirow{9}{*}{3} \\
\hline & & 繰返し & 600 & \\
\hline & & 繰返し & 900 & \\
\hline & \multirow{3}{*}{15} & 単調 & - & \\
\hline & & 繰返し & 600 & \\
\hline & & 繰返し & 900 & \\
\hline \multirow{3}{*}{$\begin{array}{c}\text { 鋼 } \\
\text { 繊維 }\end{array}$} & \multirow{3}{*}{10} & 単調 & - & \\
\hline & & 繰返し & 150 & \\
\hline & & 繰返し & 225 & \\
\hline
\end{tabular}

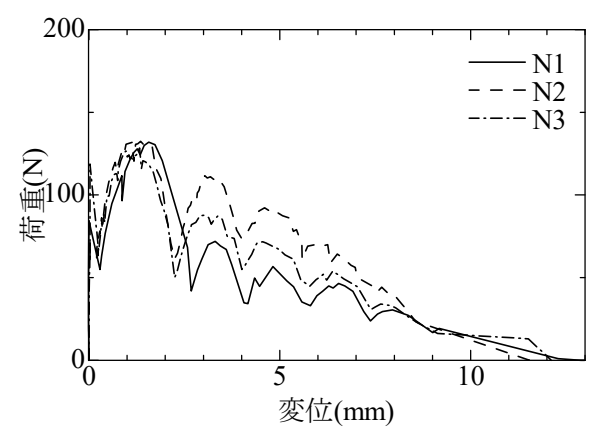

図-4 単調引抜き（PP繊維・埋込み長 10mm)

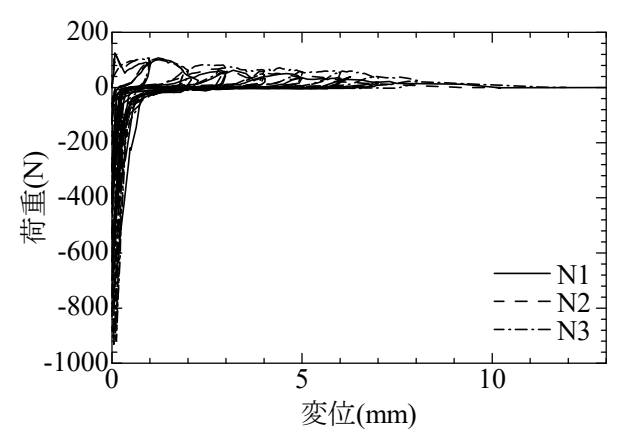

全体

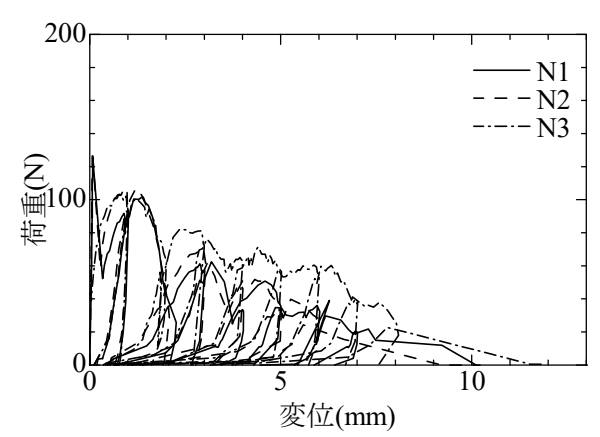

ON 以上のみ拡大（作用させる圧縮力 $900 \mathrm{~N}$ )

図-5 繰返し載荷 (PP 䋊維・埋込み長 $10 \mathrm{~mm}$ ) 


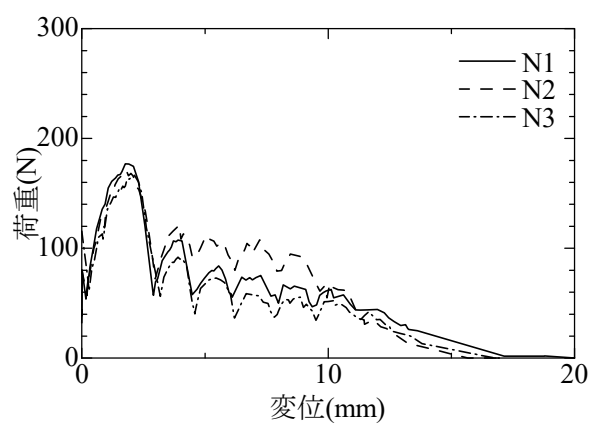

図-6 単調引抜き（PP 繊維・埋込み長 $15 \mathrm{~mm}$ )
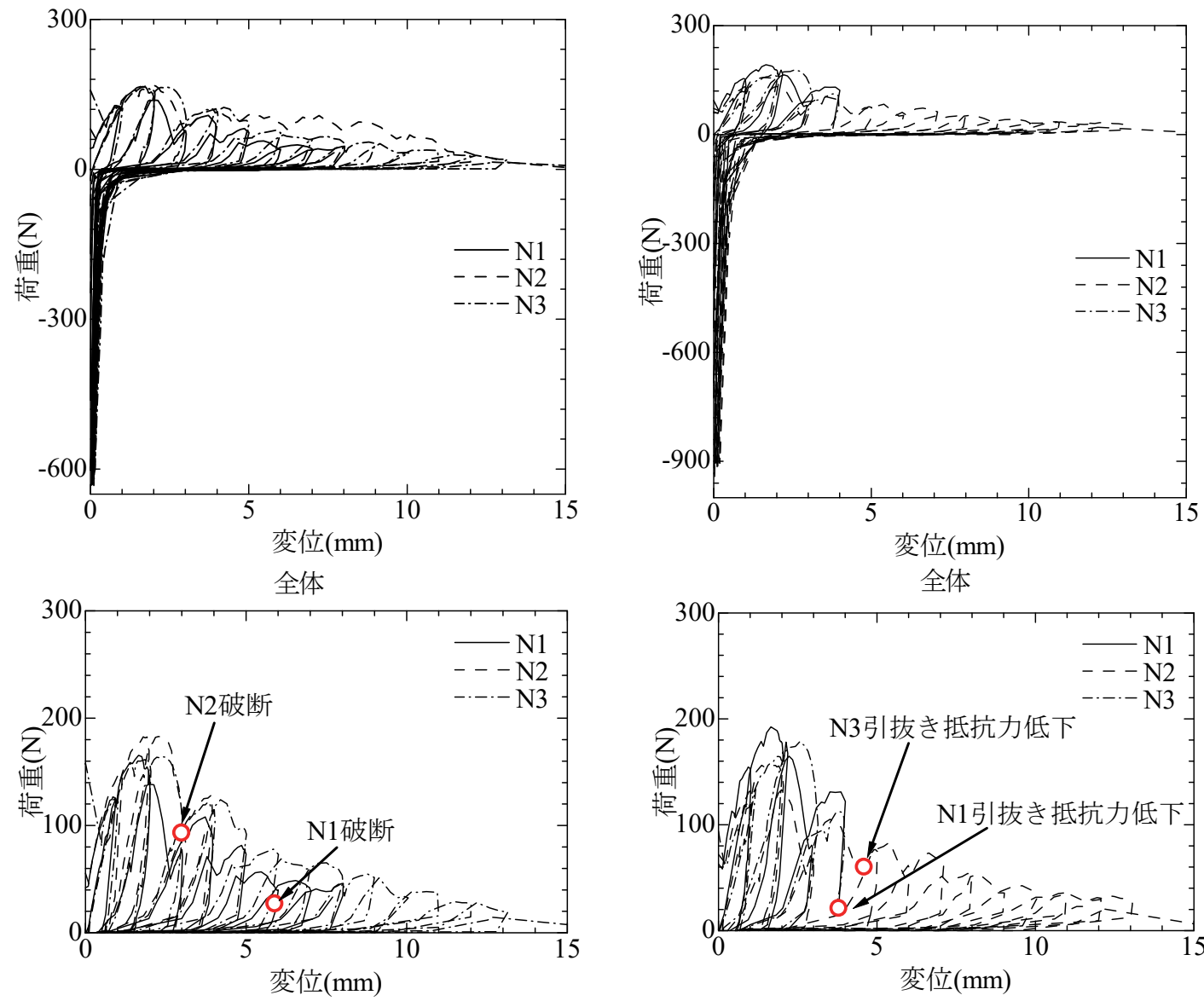

$0 \mathrm{~N}$ 以上のみ拡大（作用させる圧縮力 $600 \mathrm{~N}$ ）

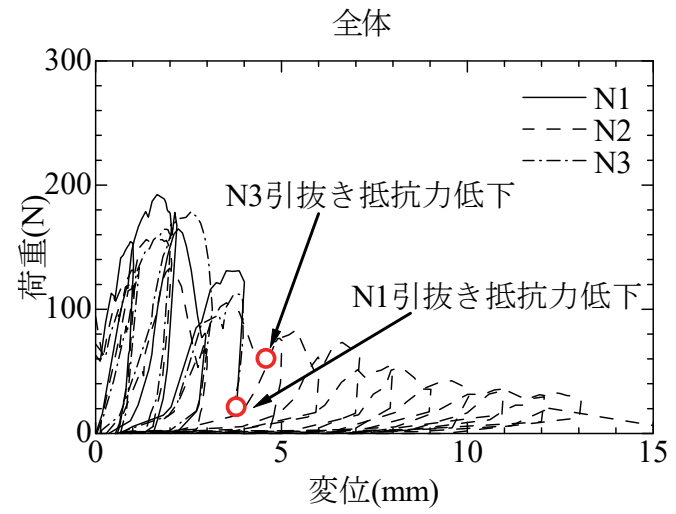

$0 \mathrm{~N}$ 以上のみ拡大（作用させる圧縮力 $900 \mathrm{~N}$ )

図-7 繰返し載荷 (PP 䋊維・埋込み長 $15 \mathrm{~mm})$

の最大変位が $1 \mathrm{~mm}$ 増加する毎に圧縮方向へ載荷し，所 定の圧縮力に到達後, 再度引張方向一載荷した. 載荷速 度が引抜き挙動に与える影響が考えられるが，本実験で は $1 \mathrm{~mm} / \mathrm{min}$.を目安とした。

\section{(4) 短繊維のパラメータ及び検討パターン}

実験の各パラメータを表-2 に示す。それぞれ埋込み 長，圧縮力について組合せを変えながら 9 パターンにつ いて実験を行った.

繰返し荷重を与える際の圧縮力については，一般的な コンクリートの圧縮強度の $1 / 3$ 程度の応力である $9 \mathrm{MPa}$
の応力をマトリクスに作用させることとした．本実験で 用いた供試体の切久き部の断面積が PP 繊維では $100 \mathrm{~mm}^{2}$ であるため，圧縮力は $900 \mathrm{~N}$ を設定した。 また，圧縮力 の違いによる短䋊維の引抜き挙動の変化を評価するため に，600N のパターンについても実験を行った．鋼繊維 の場合は切欠き部の断面積が $25 \mathrm{~mm}^{2}$ であるため $225 \mathrm{~N}$ を 設定した. PP 繊維と同様に圧縮力を変化させた $150 \mathrm{~N}$ に ついても実験を行った. 


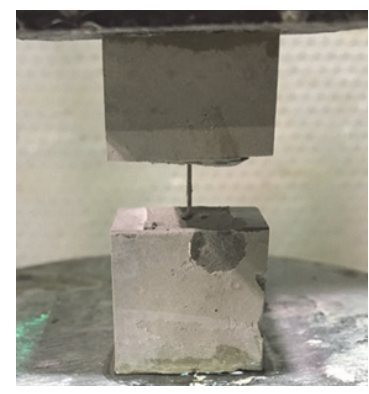

図-8 単調引抜き

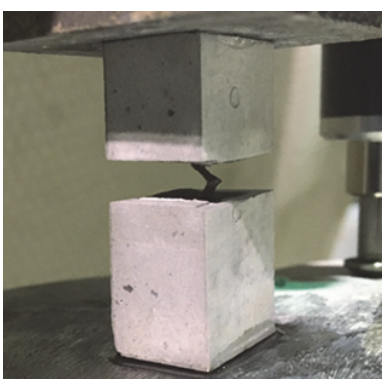

図-9 繰返し載荷

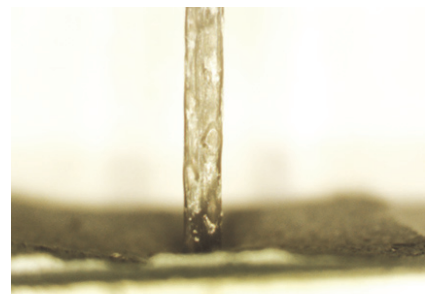

単調引抜き（N1）

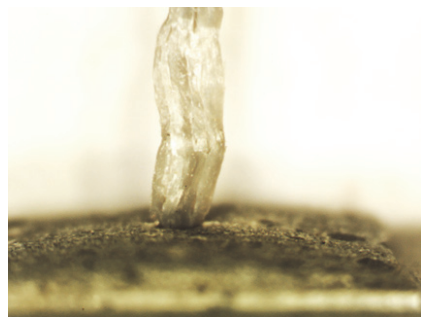

圧縮力 $600 \mathrm{~N}(\mathrm{~N} 2)$

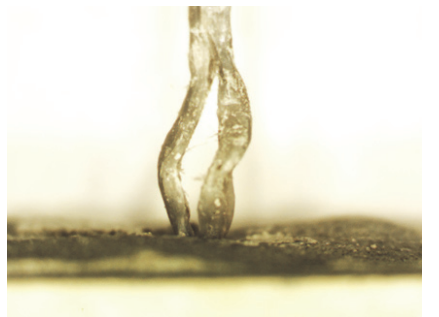

圧縮力 $900 \mathrm{~N}(\mathrm{~N} 3)$

図-10 試験後の短䋊維表面（PP䋊維・埋込み長 10mm）

\section{3. 実験結果 (PP 繊維)}

\section{（1）荷重-変位曲線}

実験により得られた荷重-変位曲線を図-4～図-7に示 す. なお，各シリーズ 3 体の供試体（N1〜N3）の結果 を示す，埋込み長 $10 \mathrm{~mm}$ においては単調引抜き及び繰返 し荷重を加えた場合においても短繊維の破断やマトリク スにひび割れが生じることはなかった，一方，埋込み長 $15 \mathrm{~mm}$ の場合には繰返し荷重を加えた際に，短繊維が破 断するものや，マトリクスに短繊維の埋込み部を起点と した割裂ひび割れが生じることで引抜き抵抗力が大幅に 低下寸るものが確認された，なお，図-4に示されるよ うに，軟化域において鋸の歯状に上下している形状は， 今回使用した PP 繊維の表面インデントによる機械的な 噛合いが影響していると推察される. なお，繰返し荷重 を与えた場合におけるインデントの影響については, 現 段階では明確ではないため, 今後の検討課題としたい.

\section{（2）試験の様子及び試験後の供試体}

単調載荷による引抜き試験の様子を図-8, 繰返し荷重 を与えた場合の様子を図-9 に示寸，繰返し荷重を受け た場合には短繊維が屈曲していることが分かる。これは 引張方向への載荷後に圧縮方向へ載荷することで抜け出 した短繊維が屈曲し, さらにその後圧縮荷重を受けたこ とで変形したためである.

試験後の短䋊維をマイクロスコープにて拡大したもの を図-10に示寸，埋込み長に関わらず，短䋊維が扁平に

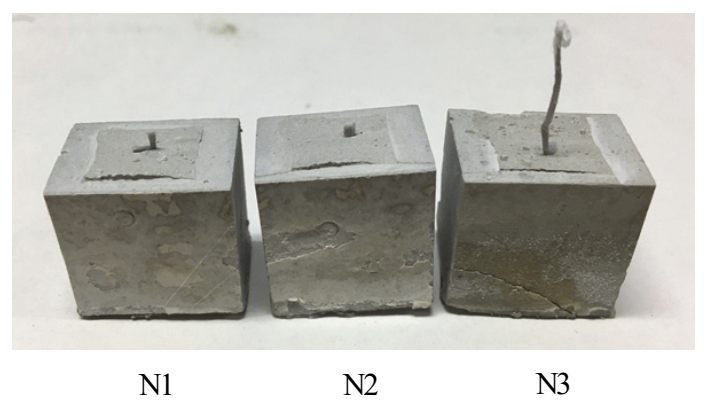

図-11 試験後の供試体（圧縮力 $600 \mathrm{~N}$ )

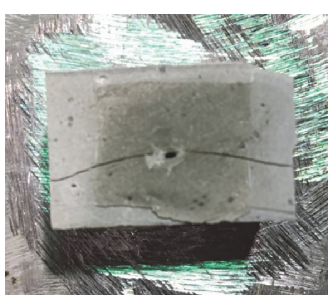

図-12 割裂ひび割れ

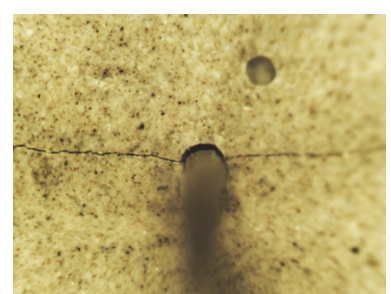

図-13 微細ひび割れ
なっているものや，2 つに裂けているものが確認された. 本実験では抜出し量を増加させながら圧縮荷重を加えた ため, 抜出し量の増加に伴って折れ目の箇所も変わって いた，そのため短繊維の損傷個所は一か所ではなく広範 囲で確認された。

\section{(3) 短絒維の破断}

埋込み長 $15 \mathrm{~mm}$ の供試体において，圧縮力 $600 \mathrm{~N}$ の際 


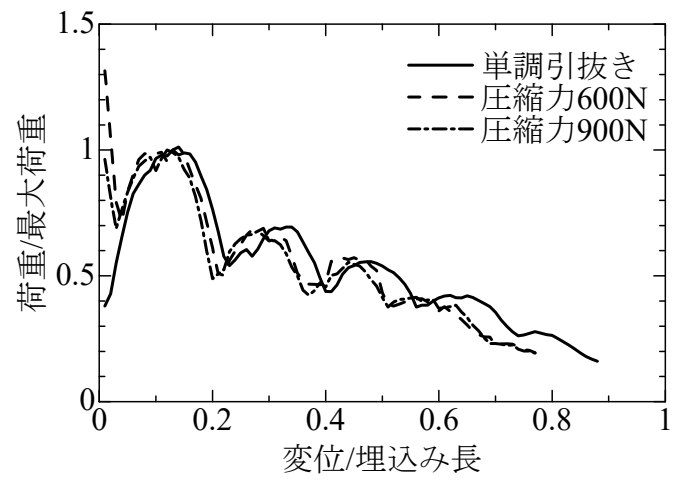

図-14 荷重/最大荷重-変位関係 (埋込み長 $10 \mathrm{~mm}$ )

に2つの供試体において短繊維の破断が確認された．試 験後の供試体を図-11に示寸．いずれの供試体も圧縮方 向への載荷を数回行った後に破断した．破断に至るまで の繰返し回数はN1 が 8 回，N2が4回であった。 また， 破断時の荷重は N1 が約 33N， N2 が約 91N であり, 繰 返し回数の増加に伴って破断強度が減少することが確認 された.

表-1 に示される短繊維の破断強度ならびに直径の公 称值を用いて計算した破断強度は $203 \mathrm{~N}$ であり, 実験值 はそれに比べて相当小さいことから繰返し作用が短繊維 の破断に与える影響も大きいことが分かる.

埋込み長 $10 \mathrm{~mm}$ の供試体においては，同様の圧縮力の 下でも短繊維の破断は確認されなかった。これは実験值 を比較すると分かるように，埋込み長が短いほど荷重值 も低下しているため, 短繊維が負担寸る引抜き抵抗力が 小さく, 破断強度に達しなかったためと考えられる.

実験を行った供試体 3 本の内, N3 は途中で短瀻維が 破断することなく最終的に埋込み部の短繊維が全て引抜 けた. 実験值をみると, 荷重值が他の 2 本の供試体に比 心゙て特段低くはないことから，短繊維の破断強度の減少 率が同程度であるとすれば破断しているはずである。供 試体は同一の水セメント比のセメントペーストを用いて 作製しているため強度は同程度である。図-10 によれば, 表面は平滑ではなく, 多少の凹凸があることが確認でき る．短繊維の損傷は上述したように，圧縮力を与える際 にひび割れ面に屈曲した短繊維が押しつぶされることで 生じるため，ひび割れ部表面の凹凸が損傷に影響を与え ていると推察される. 以上のように, ひび割れ表面の状 況によって短繊維の損傷が異なることから，供試体によ って短繊維の破断強度の減少率に差異が生じたと推察さ れる.

同様の埋込み長において，圧縮力 $900 \mathrm{~N}$ の場合には短 繊維の破断が確認されなかった。 3 本中 2 本の供試体が 次項(4)に記述する割裂ひび割れにより引抜き抵抗力が 低下したためである.

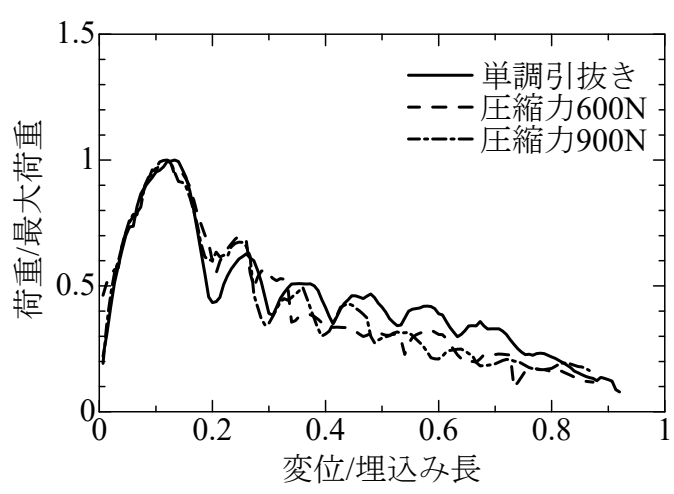

図-15 荷重/最大荷重-変位関係 (埋込み長 $15 \mathrm{~mm}$ )

これらの結果より, 本実験の範囲では $600 \mathrm{~N}$ (応力換 算で $6 \mathrm{MPa}$ ) 程度の圧縮力を受けた場合でも, 繰返し回 数によっては短繊維が破断する場合があることが確認さ れた。 また，PP 䋊維において繰返し荷重を受ける際の 引抜き挙動のモデル化には, 繰返し作用による破断強度 の減少率を同定する必要がある. 現段階ではそれらを構 築するための十分な知見が揃っていないため, 引き続き データの蓄積が必要である.

\section{(4) 割裂ひび割れ}

埋込み長 $15 \mathrm{~mm}$ ，圧縮力 $900 \mathrm{~N}$ の試験の際，マトリク スに割裂ひび割れが生じる供試体があった。図-7 に示 すように，割裂ひび割れが生じた供試体は N1 と N3 で あり， $\mathrm{N} 2$ と比較すると引抜き抵抗力が大幅に低下して いることが分かる.

実際に生じた割裂ひび割れを図-12 に示す。割裂ひび 割れはいずれの供試体においても圧縮力を与えている際 に目視にて確認された.

一方で，単調引抜き試験を行った一部の供試体で図13 にみられるような短繊維の埋込み部を発端とした微 細なひび割れが確認された。これは短繊維が引き抜かれ る際のマトリクスに埋込み部においてフープテンション を与えているためではないかと推測される，ただし，実 際の構造物では，ひび割れ面の面積が大きいことから微 細ひび割れが生じたとしても割裂ひび割れには進展しな いと考えられ，この試験方法に起因した現象であるとい える.

\section{（5）繰返し荷重が引抜き抵抗力へ与える影響}

繰返し荷重が引抜き抵抗力へ与える影響を評価するた めに，ケース毎に得られた荷重-変位関係の平均化を行 った. 平均化においては, 繰返し荷重を加えた供試体に ついては包絡線を対象とした。 また，載荷中に短繊維の 破断や割裂ひび割れによって引抜き抵抗力が低下した供 試体については，それらが生じる前までのデータを用い 


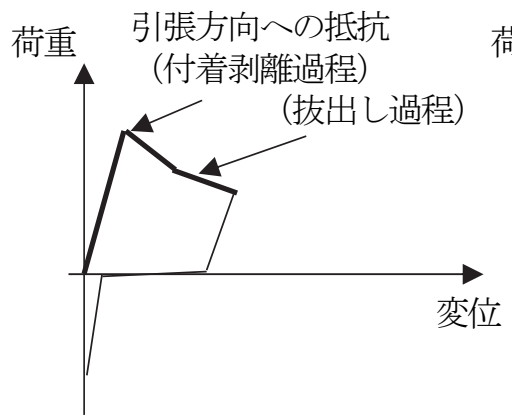

載荷過程

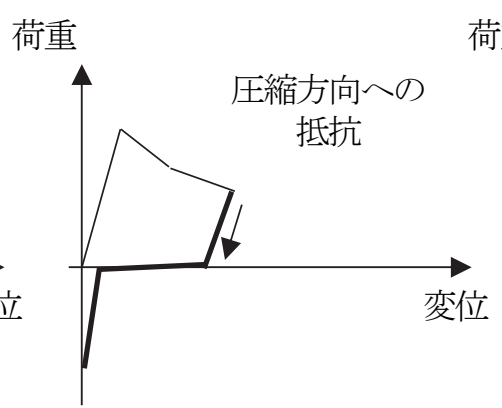

除荷過程

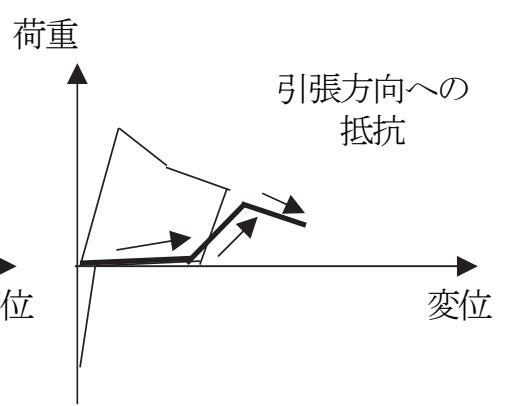

再載荷過程

図-16 抵抗挙動の模式図 (PP䋊維)

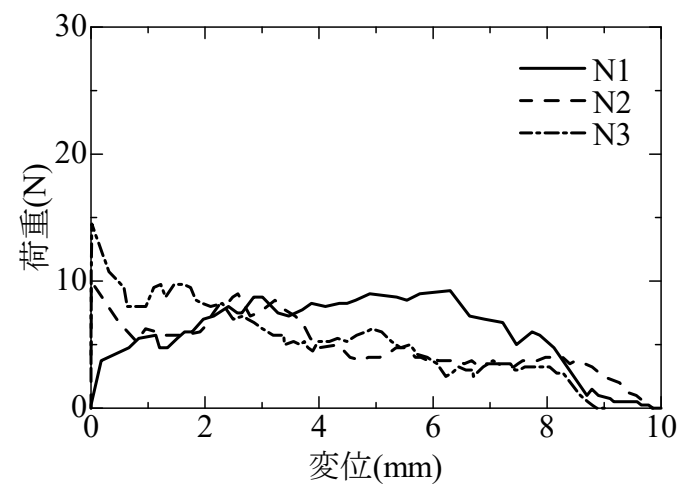

図-17単調引抜き（鋼䋊維・埋込み長 $10 \mathrm{~mm}$ )

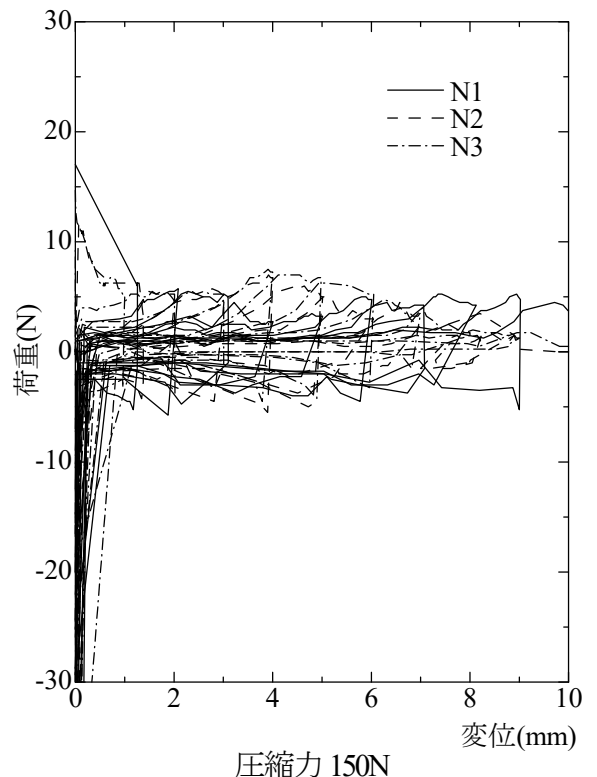

圧縮力 $150 \mathrm{~N}$

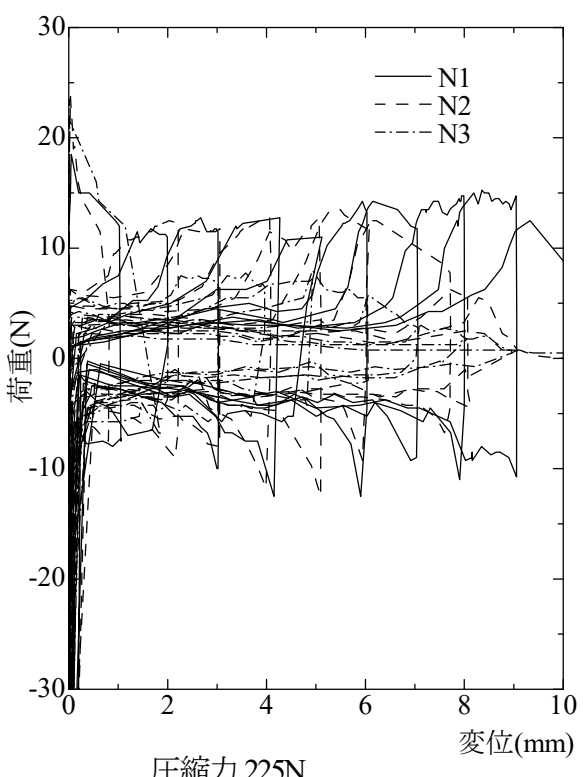

圧縮力 $225 \mathrm{~N}$

図-18 繰返し載荷（鋼䋊維・埋込み長 $10 \mathrm{~mm})$

た.

平均化した後の荷重-変位関係に対して，最大荷重と 埋込み長でそれぞれ正規化した結果を図-14 と図-15に 示す．繰返し荷重を受けた場合には引抜き過程における 荷重が僅かに低下していることが確認できた。また，埋 込み長が長いものほど, 変位の大きな領域（横軸の 0.4 より大きな領域）での荷重の低下が大きかった。一方,
圧縮力の違いによる差は確認されなかった.

図-16の模式図に示すように，PP 䋊維の引抜き挙動は， 化学付着力の損失が卓越する付着剥離過程（主に最大荷 重近傍で生じていると推察される）と繊維の形状等 （PP 繊維表面のインデントなど）に依存した機械的な 付着力や摩擦付着力が卓越している抜出し過程（主に軟 化域で生じていると推察される）に大別できる. 本実験 


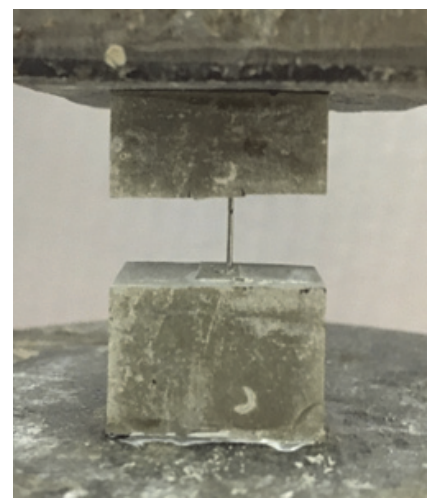

図-19 試験の様子

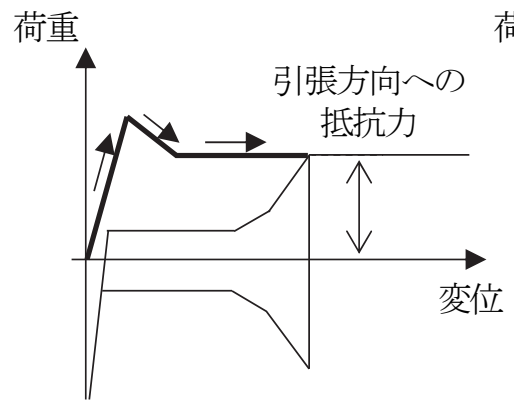

載荷過程

荷重

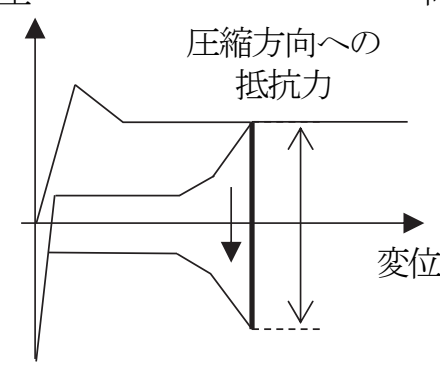

除荷過程

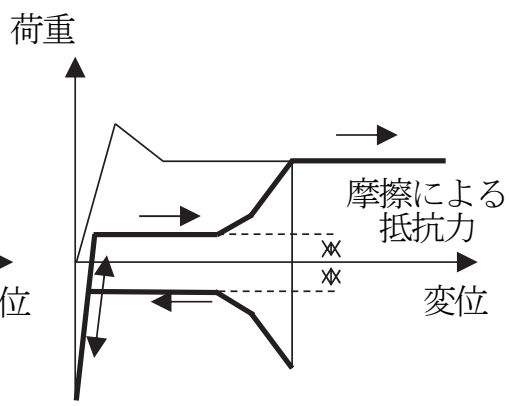

再載荷過程

図-20 抵抗挙動の模式図（鋼繊維）

によれば，最大荷重までは繰返し荷重による影響がみら れなかったことから，付着剥離過程においては繰返し荷 重を受けてもさほど影響がない．また除荷過程において は，荷重が 0 になった後は，モルタル同士が接触するま でほとんど抵抗を示さないことが分かる．再載荷過程で は，繊維の引抜き抵抗が確認できるものの，単調引抜き に比べて，やや引抜き抵抗力の低下が確認されたことか ら（図-14，15 参照），機械的な付着力や摩擦付着力が 卓越している状況では繰返し荷重の影響を受けていると 考えられる.

\section{4. 実験結果（鋼繊維）}

\section{(1) 荷重-変位曲線}

実験により得られた荷重-変位曲線を図-17，図-18に 示す. 繰返し荷重を与えた供試体については-30N まで を拡大して示している.結果より, 荷重-変位関係には ばらつきがみられた。しかしながら, 繰返し荷重を与え た場合においても抵抗力の変化が確認できないことから, 繰返し荷重は引抜き抵抗力に影響を与えないことが確認 された.

試験の際にはいずれの供試体においても短䋊維の破断 や割裂ひび割れは生じなかった。 また, 繰返し荷重を与
えた場合には引張方向から圧縮方向へ載荷方向を変えた 際に圧縮方向一の抵抗がみられた。この現象は PP 繊維 ではみられなかったことから，PP 繊維では引き抜かれ た短繊維が屈曲したが，剛性の高い鋼繊維ではそのまま 押し込まれる現象が生じたものと考えられる.

\section{(2) 試験の様子}

試験の様子を図-19 に示寸. 鋼繊維では圧縮方向へ載 荷した場合でも短繊維の屈曲が生じることはなく, 抜け 出したマトリクスへ再度押し込まれた。 また，短䋊維が 屈曲しなかったことから繰返し荷重を与えた場合でも短 繊維表面の損傷は生じなかった.

\section{（3）除荷過程及び再載荷過程における挙動}

結果から推定される鋼繊維の引抜き挙動の模式図を図 -21 に示寸. 載荷過程において引張方向への抵抗力を示 した後，除荷過程への移行で圧縮方向への抵抗力を示し た. この挙動は圧縮方向への載荷においても短繊維が屈 曲せずに再度マトリクスへ差し込まれる挙動を示してお り, 静止摩擦による抵抗力であると推測される. その後, 動摩擦による抵抗力を受けながら変位が増減している.

再載荷過程においては図-20 に示すような抵抗挙動を 示した. この抵抗挙動は引張方向及び圧縮方向の両方向 で確認され, 静止摩擦力によるものであると考えられる. 
また, 動摩擦力は, 最大引張力の $1 / 3 \sim 1 / 4$ 程度であった. 以上の結果より, 鋼緎維の抵抗力は除荷及び再載荷過程 においてもある程度発揮されることが確認された。

これらの現象は繰返し荷重を与えたすべての供試体で 確認されており, 圧縮荷重值の違いが引抜き挙動に与え る影響は確認されなかった. また, 繰返し回数が増加し ても鋼繊維の抵抗挙動には変化がみられないことから, 繰返し回数の影響は顕著ではなかった.

\section{5. まとめ}

本研究では，インデント付き PP 繊維およびストレー 卜鋼繊維を対象に，繰返し荷重を作用させた繊維の引抜 き実験を行った．本実験の範囲内で得られた知見を以下 に示す.

（1） PP 䋊維は，繰返し荷重を受けることで短繊維表面 が損傷し, 繰返し回数が増加するほど破断強度が 低下寸る傾向がみられた。また，短繊維の損傷は ひび割れ面の表面状況にも影響を受けることが示 された，一方鋼䋊維は表面の損傷は確認できず, 破断も生じなかった.

（2） PP繊維において，短繊維が引き抜かれる際にマト リクスに微細ひび割れが生じることが確認された。 微細ひび割れが生じた場合に, 圧縮荷重を与える と微細ひび割れが割裂ひび割れへと進展し，短緎 維の引抜き抵抗力が低下寸ることが確認された.

（3）鋼繊維において, 繰返し荷重における載荷過程と 除荷過程への移行の際に, 摩擦付着力による圧縮 方向への抵抗力が確認された。 また，除荷及び再 載荷過程においては, 引張方向及び圧縮方向の双 方向において摩擦付着力により最大荷重の 1/3 1/4 程度の抵抗力を示すことが確認された.

先述のとおり, インデント付き $\mathrm{PP}$ 繊維およびストレ 一ト鋼繊維を対象とした実験に基づくものであり, 引き 続きデータの蓄積および得られた結果に対する考察の妥 当性の検証が今後の課題である.

\section{参考文献}

1) Naaman, A. E. : Engineered steel fibers with optimal properties for reinforcement of cement composites, $J$. of $A d$ vanced Concrete Technology, Vol. 1, No. 3, pp. 241-252, 2003.

2) Naaman, A. E. and Reinhardt, H. W. : Setting the stage: Toward performance based classification of FRC composites, High Performance Fiber Reinforced Cement Compo- sites (HPFRCC4), Proc. of the 4th Int. RILEM Workshop, pp. 1-4, 2003.

3) Naaman, A. E. : Toughness, ductility, surface energy and deflection-hardening FRC composites, Proc. of Int. Workshop on Ductile Fiber Reinforced Cementitious Composites (DFRCC-2002), pp. 33-57, 2002.

4) Naaman, A. E. : Fibers with slip-hardening bond, High Performance Fiber Reinforced Cement Composites (HPFRCC3), Proc. of the 3rd Int. RILEM Workshop, pp. 371-385, 1999.

5) Li, V. C. : On engineered cementitious composites (ECC) A review of the material and its applications, J. of $\mathrm{Ad}$ vanced Concrete Technology, Vol. 1, No. 3, pp. 215-230, 2003.

6) Li, V. C. : From micromechanics to structural engineering - The design of cementitious composites for civil engineering applications, J. of Struct. Mech. Earthquake Eng., No. 471/I-24, pp. 37s-48s, 1993.

7) Li, V. C. : Reflections on the research and development of engineered cementitious composites (ECC), Proc. of Int. Workshop on Ductile Fiber Reinforced Cementitious Composites (DFRCC-2002), pp. 1-21, 2002.

8) Li, V. C., Wang, Y. and Backer, S. : Effect of inclining angle, bundling, and surface treatment on synthetic fiber pull-out from a cement matrix, Composites, Vol. 21, No. 2, pp. 132-140, 1990.

9) Kanda, T. and Li, V. C. : Interface property and apparent strength of a high strength hydrophilic fiber in cement matrix, J. of Materials in Civil Engineering, ASCE, Vol. 10, No. 1, pp. 5-13, 1998.

10) Bolander, J. E. and Saito, S. : Discrete modeling of shortfiber reinforcement in cementitious composites, Advanced Cement Based Materials, Vol. 6, pp. 76-86, 1997.

11) Bolander, J. E. : Spring network model of fiber-reinforced composites, High Performance Fiber Reinforced Cement Composites (HPFRCC3), Proc. of the 3rd Int. RILEM Workshop, pp. 341-350, 1999.

12) Kunieda, M., Ogura, H., Ueda, N. and Nakamura, H. : Tensile fracture process of strain hardening cementitious composites by means of three-dimensional meso-scale analysis, Cement and Concrete Composites, Vol33, pp. 956-965, 2011.

13）小倉大季, 国枝稔, 中村光 : 鉄筋補強した繊維補強 セメント系複合材料の引張破壊解析と架橋力に着目 した破壊挙動評価, 土木学会論文集 E2, Vol. 72, No. 3, pp. 249-267, 2016.

14）幸左賢二，小川敦久，合田寛基，脇田和也：高靭性 セメント巻き立て厚に着目した耐震補強実験高勒性 セメント巻き立て厚に着目した耐震補強実験, 構造 工学論文集, Vol. 55A, pp. 1024-1035, 2009.

15) 平田隆祥, 石関嘉一, 竹田宣典 : 「ユニバーサルク リート」の橋梁への適用性評価, 大林組技術研究所 報, No. 75, pp. 1-6, 2011.

(2018. 9. 25 受付) 


\section{FIBER PULL-OUT RESISTANCE BEHAVIOR SUBJECTED TO MONOTONIC AND CYCLIC LOADINGS}

\section{Yasuhiro NAKAYA and Minoru KUNIEDA}

This paper presents test results of pull-out behavior of short fiber (PP fiber and steel fiber) subjected to monotonic and cyclic loading. In the case of PP fiber, pull-out resistance under cyclic loading was slightly decreased comparing to that of monotonic loading. In some cases, load was suddenly dropped due to split crack due to cyclic loading. In addition, bending of PP fiber induces a damage due to compression action in the test. In the case of steel fiber, frictional bonding behavior was observed in both tensile and compression phases. 